Journal of Teacher Education for Sustainability, vol. 17, no. 2, pp. 74-90, 2015

\title{
Innovative and Traditional Elements in the Work of Academic Staff: The Views of Pre-service Teachers
}

\author{
Inese Jurgena and Dagnija Cēdere \\ Riga Teacher Training and Educational Management Academy, Latvia \\ Ingrīda Keviša \\ Latvian Academy of Culture, Latvia
}

\begin{abstract}
The academic staff of the institutions of higher education plays a key role in the implementation of innovations in the study process. This article aims to analyze the views of students, pre-service teachers, on the role of innovations and traditions in the work of the academic staff at their institution of higher education. The survey data from 192 full-time and part-time first year students at Riga Teacher Training and Educational Management Academy show that readiness for innovative activity and active involvement in the creation, acquisition and implementation of innovations is an essential factor in the work of the academic staff. The results indicate that according to the views of preservice teachers, in the context of pedagogy, the term 'innovation' refers to the process of renewal, educational reforms, selection of the most appropriate teaching material, and the elaboration, adoption and utilization of innovations in the pedagogical practice.
\end{abstract} Keywords: pre-service teachers, innovation, tradition, academic staff, higher education

In the 21st century, each individual and the society as a whole have to learn to live in the constantly changing environment, to coexist with changes and to make change themselves. Along with the shift in the educational paradigm, significant transformations take place in educational systems. The policy planning documents of the Republic of Latvia state that individuals with their knowledge, wisdom and skills, as well as the willingness to actively cultivate and apply them, are Latvia's main resource on the way towards the knowledge society. These documents emphasize that "the extensive and deep high-quality knowledge, together with the human capital, is a precondition for the eco-system of innovations to create new knowledge" (The Cabinet of Ministers of the Republic of Latvia, 2013, p. 43).

Knowledge is becoming the main driving force for the development in all areas of human activity. Therefore, it is very important to reform the system of education so that it could meet the increasing demand for new knowledge. Investing in human capital 
in the knowledge driven society actually means creating not only new knowledge, but also new marketable and competitive products or services, thus enhancing the wellbeing of the whole society.

Within the model of the learning society, innovations in education can be applied to change human thinking, the understanding of values, and to erase the boundaries between the formal and informal education. The notion of the knowledge society is closely linked with the development of information and communication technologies, though the wide use of digital technologies in education poses new challenges (Kapenieks \& Salìte, 2012; Woods, 2002). Besides, technologies lead to changes in human thinking and perception (Prensky, 2001).

Nowadays, the issues concerning the innovative ability of the institutions of higher education are more topical than ever before, both in Latvia, Europe, and the whole world. However, there are comparatively few studies concerning transformations in the Latvian institutions of higher education (Gedžūne, 2014; Lukjanska, 2014; Tisenkops, Bela, \& Kunda, 2011), and they mainly deal with the analysis of structural changes within these institutions. The issues regarding the innovation processes underlying the changes and the realization of the diverse roles of educational institutions, as well as students' views on the implementation of innovations in educational institutions have been studied much less.

The changes in the system of teacher education toward sustainability are among the possibilities to change the educational system in Latvia. The essence of sustainable higher education is to ensure individual's ability to adapt to the conditions of the changing environment, to prepare people for professional activity in the information society, and to create opportunities for everyone to develop himself/herself creatively (Grabovska, 2006).

The refocusing of education toward sustainability is particularly topical in teacher education since teachers are entrusted with the responsibility to take care of young people - the new link in the chain of the evolution of human consciousness (Fried, 2006; Grabovska \& Grabovskis, 2009; UNESCO, 2005). In scientific literature, the goals of teacher education are linked with the attempts to help would-be teachers reach sustainability, i.e. inclusive wisdom (Salīte, Gedžūne, \& Gedžūne, 2009). The refocusing of students - pre-service teachers toward the aim of sustainability also includes the issue of innovations in the process of studies.

However, the system of higher education in Latvia, including professional teacher training, shows some contradictory elements. Undoubtedly, the academic staff working in the institutions of higher education ensures the passing of knowledge, skills and values on to the new generation (Baltušite, 2012; Mūrnieks, 2010). Nevertheless, according to a number of studies, the active involvement in the creation and acquisition of innovations, as well as the use of innovations in the study process is not observed on a regular basis in the work of the academic staff at the institutions of higher education (Baltušite, 2012; Brigmane, 2014; Kunda, 2014; Kapenieks, 2013). With regard to the quality of higher education in Latvia, particular attention is paid to the issues concerning teaching methods, technological provision, and the possibilities of information and communication technologies, while the focus on the key subject - the student - is not sufficient (Kapenieks, 2013; Lapina, 2007; Stankevičs, 2015).

What is the students' attitude toward innovations and traditions in the study process and what do they expect from the studies? Are students oriented towards innovative 
activity? Are the relationships between the students and teachers based on mutual interest and collaboration, and what is necessary to improve them? What is the role of the personal qualities of the academic staff in the study process? These are the key questions, the answers to which can be found through the reflection and self-report study of preservice teachers.

Therefore, the purpose of our study was to analyze the views of pre-service teachers on the manifestations and the role of traditions and innovations in the work of the academic staff at their institution of higher education.

\section{Theoretical Background}

Along with the paradigm shift in education in the new social and economic conditions that mark the last decades for the society of Latvia, there has appeared the need to bring to the foreground the issue concerning innovations and traditions in education.

According to Robinson (2011), a paradigm is a generally accepted framework of a set of rules and considerations which determines progression and the way something is done. At present, all philosophical approaches recognize the transition to a new global paradigm where people are participants in common research (Reason \& Bradbury, 2008). This has been referred to as an evolution in philosophical thinking. Essentially, a shift in the way of thinking is a paradigm shift. As one of the global paradigms, the paradigm of the knowledge society has a direct impact on the development of research in many disciplines, including pedagogy (Kapenieks, 2013; Lapin,a, 2007; Stankevičs, 2015).

The notion of 'innovation' has been derived from the Latin word innovare, which means "to renew or change"; consequently, innovation is something new - an idea, a practice, or an object. However, being new is not an end in itself; it is something that makes it possible to reach an aim of a particular social entity in a more successful, effective, and economical way than something "old"; it stimulates productivity, competitiveness, survival (Alange, Jacobsson, \& Jarnehammar, 1998), constant renewal and the preservation of vitality (McKenzie, Aleksander, Harper, \& Anderson, 2005). The chief business of traditional education is to transmit to the next generation those skills, facts, and standards of moral and social conduct that adults consider being necessary for the next generation's material and social success (Dewey, 1938).

Studies concerning innovations and traditions have been carried out in various disciplines - culture, economics, and social sciences. In the present study, the authors have tried to present the analysis of the understanding of these concepts in the field of higher education. With regard to the innovative and traditional aspects of higher education, it is important that universities are able to adapt to the new reality of knowledge creation, which is essentially different from the traditional way of knowledge creation and implementation in the existing institutional framework.

Starting from the 1980s, innovations and changes have become the key notions in the policy and practice of higher education in the West (Silver, Hannan, \& English, 1997). At universities, innovation was regarded as an instrument to ensure legitimacy and survival adapting to changes in the environment (Stensaker \& Norgard, 2001). According to Silver and his colleagues (1997), innovation has to be regarded as a planned process at the university during which changes are introduced in order to make improvements or to solve or minimize some practical problems. This definition is very neutral 
and can suit any environment. It implies the procedural character of innovations, their purposefulness, the focus on improvement, and the solution of a problem.

According to the studies, innovations can take place within the framework of all the traditional roles of universities - the process of studies, research, and social engagement (McKenzie et al., 2005; Shattock, 2008). Nevertheless, a considerable part of innovations is searched for and found with regard to the process of studies, thus confirming that the provision of higher education is the main (or most visible) contribution of the institutions of higher education to society. There have to be pointed out discussions concerning the degree of innovations, which directly refer to the issue of new solutions and the ability to find legitimacy in the practice of a particular organization.

In scientific literature, two degrees of innovations - the incremental (gradual) and the radical one (Brunori, Berti, Kleikx, Tisenkopfs, \& Rolp, 2011) have been singled out. Incremental innovations can be introduced with a few changes in the existing organizational practice; they fit in the context of the current norms and values, while radical innovations require major changes both in the institutional practice and the norms and values (McKenzie et al., 2005). A radical innovation disrupts the existing practice and contradicts the institutionalized understanding of what is acceptable, appropriate, and desirable (Van Dijk, Berends, Jelinek, Romme, \& Weggeman, 2011). Nevertheless, it has been pointed out that radical innovations are also possible in stable and distinctly institutionalized environments (Zietsma \& Lawrence, 2010). All in all, the scholars point out, that incremental innovations dominate in the institutions of higher education (McKenzie et al., 2005; Silver et al., 1997).

Within the context of the present study, the characteristics of top-down and bottomup innovations and their role in the institutions of higher education, i.e. the origin of initiatives related to innovations and their direction, will be considered in the interpretation of the results. The majority of studies concerning the changes in universities tend to consider top-down innovations, i.e. changes proposed by formal administrative structures.

Since 2009, an intensive discussion has been going on in Latvia concerning the quality of higher education. There have been proposed political reform initiatives that envisage changes in administration and management. At present, as far as the creation of innovations is concerned, initiative is primarily associated with formal power positions. A comparatively small number of empirical studies are devoted to the analysis of bottomup innovations. In the institutions of higher education, innovations are associated with harsh competition, tension, and acute necessity to deal with financial problems rather than creativity and individual enthusiasm (Kunda, 2014; Stankevičs, 2015).

The positive outcomes of bottom-up innovations discussed in the theoretical literature are due to a greater variety of solutions initiated by various stakeholders (Kezar, 2012) as well as incremental improvements of the existing practice (Cummings, 2005) like improvements in the curricula and student-teacher interaction. As far as the survival of universities is concerned, bigger hopes are linked with improvements in interaction, expecting that new methods can improve the quality of studies and reduce the needed effort at the same time. Innovations concerning the process of studies and interaction can manifest themselves as the use of technologies, the creation of particular skills, the use of teamwork, e-learning, mentoring, etc. (Hannan \& Silver, 2000). A comparatively smaller number of studies have been devoted to innovations and traditions in the work of academic staff at the institutions of higher education. 
In the studies concerning competencies, it has been emphasized that in the future the most demanded professions will be those requiring competencies for innovative activity (CEDEFOP, 2008). It is particularly important for the work of the academic staff at the institutions of higher education.

The authors have identified several studies on the innovations in the field of pedagogy (Kapenieks, 2013; Kettunen, Kairisto-Mertanen, \& Penttila, 2013; Lapina, 2007). The innovation capacity of an innovative specialist - a university teacher - can be characterized by his/her competence to create, develop, and commercialize new competitive products (Lapin,a, 2007). According to Lapiña (2007), the individual's innovation capacity is determined by three factors: specific personal qualities, theoretical and professional knowledge in a particular field, and the environment favorable to innovations or innovation culture.

The notion of the knowledge society cannot be separated from the development of information and communication technologies. Technologies play a decisive role in students' lives; they can make the learning environment more innovative and creative. The skills of students and educators, together with the educational systems based on new technologies, create a new learning culture focused on learners' needs (Ferrari, Cachia, \& Punie, 2009; Prensky, 2005). The sustainable use of technologies provides opportunities for a creative study process, facilitates the possibilities of knowledge creation, expands the possibilities of cognition, as well as the engagement and motivation of users (Kapenieks, 2013). The application of new information technologies in the process of studies is one of the most essential elements of the innovative activity of the academic staff.

Studies on the educational practice of academic staff also bring to the foreground the issue concerning the interaction of traditional and innovative teaching methods in the study process. With regard to a student survey about the possibilities of using the lecture as a traditional teaching method, Cavanagh (2011) points out that students appreciate lectures that combine information given by a teacher with cooperative learning tasks, opportunities to work in small groups and have discussions. The other study (Miller, McNear, \& Metz, 2013) shows that students' participation in lectures combined with involvement in discussions and group work leads to better acquisition of information and understanding, higher interest and motivation, and better results in examinations.

The aforementioned issues have also been tackled in the studies related to higher education and teacher training in Latvia (Baltušite, 2012; Lapiña, 2007). The institutions of higher education create the educational environment developing the readiness of future specialists for their professional activity. In the field of education such an activity comprises a set of qualities that can been accumulated as a result of positive experience, the inner potential of successful pedagogical activity, as well as the availability of resources for purposeful activity (Baltušite, 2012).

Therefore, considering all the above, pre-service teachers' views are very important in order to understand the significance of innovative and traditional aspects in educating future teachers.

As was already mentioned, educators' professionalism is a particularly important precondition for the successful development of any institution of higher education, also in the context of innovations and traditions. In order to gain a comprehensive idea of processes taking place at the institutions of higher education, our study was aimed at clarifying students' views in two aspects: 
- What are the students' views concerning innovative and traditional elements in the work of academic staff at their institution of higher education?

- How do the students evaluate the role of teacher's personality in the innovative process of studies?

\section{Methods}

\section{Instruments}

In order to clarify the students' views on innovative and traditional elements in the work of academic staff at their institution of higher education, the authors designed two questionnaires containing questions regarding the students' 1 ) orientation toward their own innovative activity and 2) attitude and expectations in relation to innovations and traditions in the process of studies. Also, these questionnaires intended to define 1) if the student/teacher relationships are based on mutual interest and collaboration, and 2) to establish the factors for the improvement of these relationships. The role of the personal qualities of teachers was also examined using these two instruments.

The questionnaires were created based on the theoretical guidelines (Kunda, 2014; Mūrnieks, 2010) mentioned above, previous studies, and Latvia's Guidelines for Science, the Development of Technologies and Innovations for the Period of 2014-2020 (The Cabinet of Ministers of the Republic of Latvia, 2013).

The questionnaires were designed to conduct an operational student survey that would give an overall impression of students' views. The first questionnaire contains items that show the respondents' views on innovations and traditions in the study process in general; the second questionnaire is intended for a more detailed exploration of the students' views concerning the role of the academic staff in the study process. Generally, the items used in both questionnaires were questions with dichotomous answers (yes/ no). In order to reflect the variety of respondents' views, more detailed sub-questions were elaborated for the items of the second questionnaire. Some items of the second questionnaire were designed using 4-point Likert scale.

Descriptive statistics (frequency, mean, standard deviation) has been used for the initial analysis of the data. Pearson Chi-Square test $\left(\chi^{2}\right)$ has been applied to evaluate correlations between two independent groups and two variables. Contingency coefficient $(\phi)$ has been used to interpret the strength of correlation between two variables measured in the dichotomous scale.

\section{Participants and Procedure}

The participants of the study were 192 first-year students of Riga Teacher Training and Educational Management Academy (RTTEMA), pre-service teachers, enrolled both in the full-time and part-time studies in various specialization groups - the future primary school teachers, elementary school teachers, the teachers of dance and rhythmic, music teachers, and education managers. The number of the respondents is sufficient for statistical analysis, the sample represents various student groups and it can be considered as representative of the overall view of the $1^{\text {st }}$ year students of RTTEMA. There were 185 women and 7 men among the respondents, 119 students participated in the first survey, with $58 \%$ full-time and $42 \%$ part-time students among them. The second questionnaire was completed by 75 full-time students. 
The data collection was organized at the end of the academic year when the respondents had become acquainted with the academic environment at the institution of higher education. This is the time when students are open for discussions and various activities, and the new experience of students' life creates the desire to exchange thoughts and critically evaluate the process of studies. The survey was conducted in the spring of 2014. All the respondents participated in the survey voluntarily. The responses were anonymous; the data have been used only in a processed form.

\section{Results}

\section{The Innovative and Traditional Elements in the Process of Studies}

According to the results of the first questionnaire, in general, the students are open to innovations in higher education; however, they believe that it is necessary to preserve the traditional aspect as well. The respondents' views can be illustrated by the answers concerning the possible ways of introducing innovations. The questionnaire's items with the highest degree of agreement or disagreement are represented in Figure 1. The numbers show that the majority of the respondents $(71 \%)$ believe that it is necessary to introduce separate innovations while preserving the results achieved with traditional methods (item A3). A similar number of the respondents ( $72 \%$ ) have given an affirmative answer to the question whether the administration of the institutions of higher education has to undertake responsibility for innovative activities (A5). However, a considerable number of the respondents ( $9 \%$ and $12 \%$ respectively) have not answered these questions, most probably due to their lack of experience. At the same time, there is a relatively high level of consensus among the respondents concerning the attitude of students and teachers to innovative processes at the institution of higher education, which were rated positively by $87 \%$ of the respondents (A10).

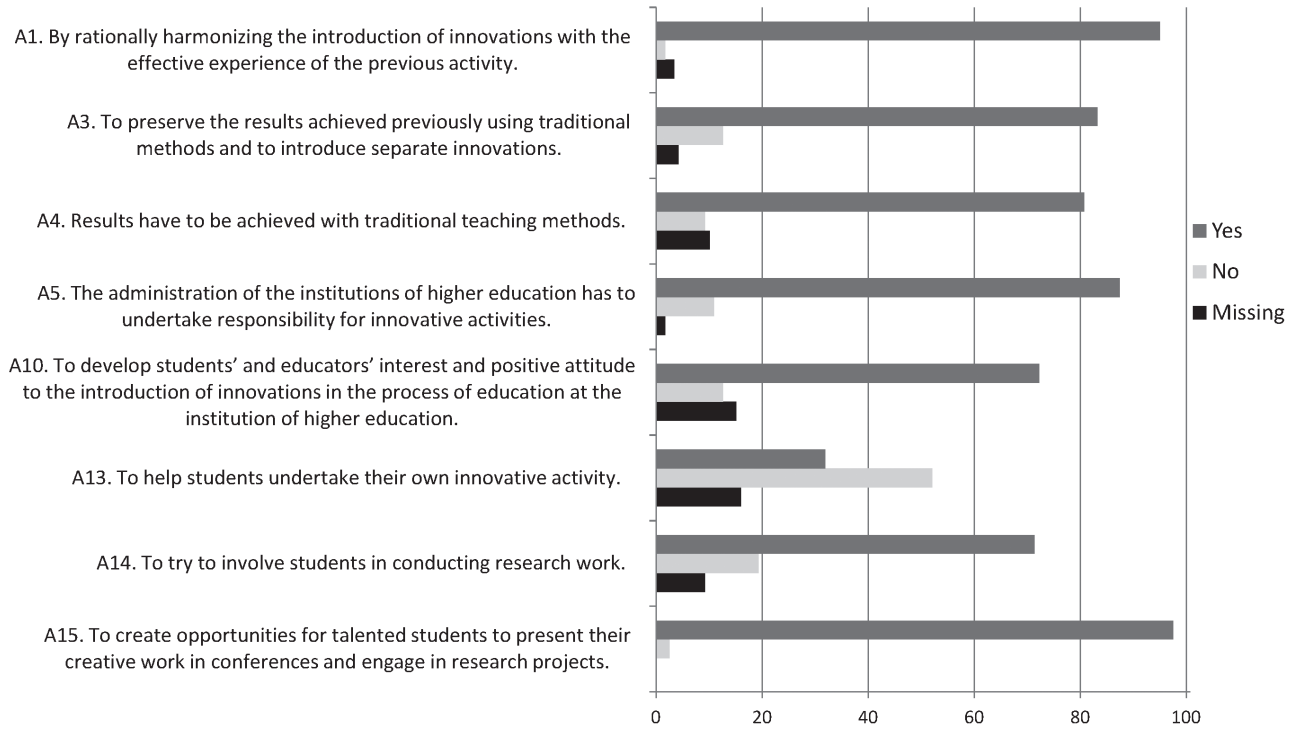

Figure 1. Students' views concerning the innovations and traditions in higher education 
Items A13-A15 (see Figure 1) characterize the students' views on innovative activities showing their positive attitude to innovations in the process of studies and potential readiness to participate in them. It can be realized that more than $80 \%$ of the respondents would be interested in undertaking their own innovative activity: they are willing to participate in research projects and present their creative work at scientific conferences, which implies that the majority of the students see their innovative activity in the area of research work, and they are ready to engage in it. Comparing the questionnaire's items in Figure 1, statistically significant differences can be identified only between the following statements: A13 and A14 $\left(\chi^{2}(1, N=89)=6.19, p=.01\right)$; A13 and A15 $\left(\chi^{2}\right.$ $(1, N=102)=9.39, p=.002)$; A14 and A15 $\left(\chi^{2}(1, N=109)=14.11, p<.001\right)$. As shown by the contingency coefficient, the correlation between the variables is moderately strong $(\phi=.30-.36)$. Thus, a number of students have no desire to get involved in the creation of the innovative learning environment or to participate in research activities. There are no statistically significant differences between the views of full-time and parttime students (Table 1).

Table 1

Comparison of Full-time and Part-time Students' Views on the Introduction of Innovations

\begin{tabular}{|c|c|c|c|c|c|c|}
\hline \multirow{2}{*}{ Items* } & \multicolumn{3}{|c|}{ Respondents $(\mathrm{N})$} & \multirow{2}{*}{ df } & \multirow{2}{*}{$\chi^{2}$} & \multirow{2}{*}{$\mathrm{p}$} \\
\hline & Total & Full-time students & Part-time students & & & \\
\hline A1 & 118 & 69 & 49 & 1 & 0.09 & .77 \\
\hline A3 & 107 & 62 & 45 & 1 & 0.02 & .90 \\
\hline A4 & 99 & 58 & 41 & 1 & 0.01 & .91 \\
\hline A5 & 100 & 59 & 41 & 1 & 3.22 & .07 \\
\hline A10 & 116 & 68 & 48 & 1 & 0.05 & .12 \\
\hline A13 & 100 & 62 & 44 & 1 & 0.13 & .71 \\
\hline A14 & 113 & 67 & 46 & 1 & 0.25 & .61 \\
\hline A15 & 114 & 66 & 48 & 1 & 0.05 & .82 \\
\hline
\end{tabular}

Note. ${ }^{*}$ See items in Figure 1

Students recognize the role of new technologies in the process of studies and link the introduction of innovations to these technologies. For instance, $96 \%$ of the respondents have pointed out that it is important both for students and educators to receive information about new technologies and to find a possibility to acquire them. The students' opinions about the introduction of innovations with the effective experience of the previous activity $(\mathrm{A} 1, M=1.03, S D=.16)$ and opportunities for talented students to present their creative work (A15, $M=1.02, S D=.13$ ) are similar.

\section{The Role of Teacher's Personality in the Innovative Process of Studies}

In order to explore the views of students on the role of the academic staff in the innovative process of studies, the respondents were offered a second questionnaire. The authors aimed to focus on the students' opinions concerning their teachers as personalities, organizers, and managers of the study process, as far as it was possible for the students to get to know that in the course of one academic year. 
The majority of the respondents $(96 \%)$ believe that teachers play an important role in students' lives. The students provided various answers to the question How has the attitude of the society to the profession of higher education teachers changed? Almost a half of the respondents $(44 \%)$ have no clear idea about the attitude of the society, while the third of the respondents $(32 \%)$ think that the prestige of the teachers working at the institutions of higher education has increased (Figure 2). Responding to the question whether the teachers can be advisors for students, the respondents have generally given a positive answer; nevertheless, $5 \%$ of the respondents believe that a teacher cannot be an advisor for students (Figure 3). This view requires further research.
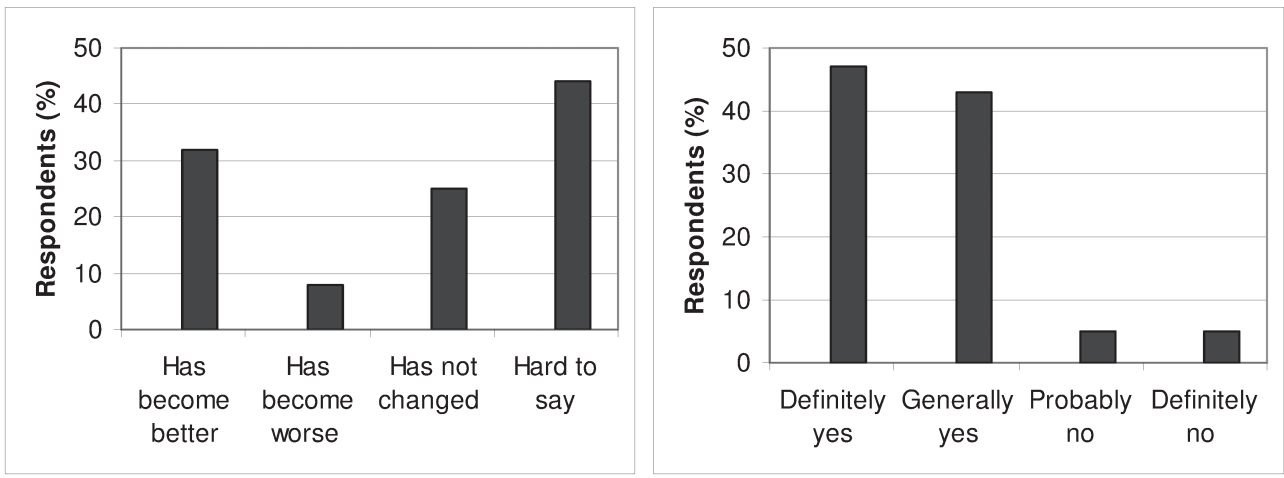

Figure 2. Students' views on changes in the Figure 3. Students' views on teachers being societal attitude toward the teachers higher advisors for students education

When evaluating the personal qualities of the academic staff, $84 \%$ of the respondents appreciate educators' professionalism, intelligence $(72 \%)$, the ability to express their thoughts clearly, and persuasiveness (73\%). Educators' respectful attitude to students' has also been given a high ranking by $71 \%$ of the respondents. Majority of the respondents $(67 \%)$ impart the positive evaluation of the teachers' interest in their subject and erudition. Small number of respondents suggests that their teachers are indifferent, haughty, or self-seeking (11\%, 3\%, and $14.7 \%$ respectively). On the other hand, only $20 \%$ of the sample has marked the teachers' selflessness and belief in high ideals. Ranking the educators' personal qualities according to the number of the respondents who have evaluated the particular quality positively, it can be seen that professionalism has obtained the highest rank (Table 2).

Table 2

Evaluation of Academic Staff's Personal Qualities by the Students

\begin{tabular}{llc}
\hline Rank & \multicolumn{1}{c}{ Personal quality of academic staff } & Number of respondents (\%) \\
\hline 1 & Professionalism & 84 \\
\hline 2 & Ability to express one's ideas clearly, persuasiveness & 73 \\
\hline 3 & Intelligence & 72 \\
\hline 4 & Respectful attitude to students & 71 \\
\hline
\end{tabular}

Sequel to Table 2 see on p. 83. 
Sequel to Table 2.

\begin{tabular}{llc}
\hline Rank & \multicolumn{1}{c}{ Personal quality of academic staff } & Number of respondents (\%) \\
\hline 5 & Erudition & 67 \\
\hline 6 & Enthusiasm for one's teaching subject & 67 \\
\hline 7 & Self-respect & 60 \\
\hline 8 & Perseverance & 55 \\
\hline 9 & Honesty & 44 \\
\hline 10 & Moral stability & 44 \\
\hline 11 & Selflessness & 20 \\
\hline 12 & Belief in high ideals & 20 \\
\hline 13 & Modesty & 19 \\
\hline 14 & Conformism & 19 \\
\hline 15 & Self-seeking & 15 \\
\hline 16 & Indifference to students & 11 \\
\hline 17 & Unwillingness to accept the views of other colleagues & 9 \\
\hline 18 & Haughtiness & 3 \\
\hline
\end{tabular}

With regard to the evaluation of relationships between teachers and students, the dominant qualities are friendliness and mutual trust. Just a very small number of the respondents have observed the conflicting relationships in the academic environment $(4 \%)$. Hostile relationships can also be regarded as an insignificant phenomenon since only $1 \%$ of the respondents characterize the relations between students and teachers in that way (Table 3).

Table 3

Evaluation of the Relationships between Teachers and Students by the Students

\begin{tabular}{clc}
\hline No & The nature of the relationship & The number of affirmative responses $(\%)$ \\
\hline 1 & Friendly & 60 \\
\hline 2 & Trusting & 52 \\
\hline 3 & Indifferent & 20 \\
\hline 4 & Tense & 8 \\
\hline 5 & Conflicting & 4 \\
\hline 6 & Hostile & 1 \\
\hline
\end{tabular}

The respondents who consider teachers to be their spiritual advisors also notice the friendly relationships between teachers and students. The strength of the correlation is characterized as follows: $\phi=.37\left(\chi^{2}(1, N=73)=11.54, p=.001\right)$. There can also be observed the strong correlation between the views that a teacher can be a spiritual advisor and a teacher plays a very important role $\left(\phi=.33 ; \chi^{2}(1, N=73)=8.34, p=.004\right)$.

When evaluating the teaching activity of the academic staff in general, students had to answer two questions - How does the institution of higher education train students for practical work at school? and How does the institution of higher education prepare students for competition in the labor market? With regard to the teacher's work at school, the respondents' answers were as follows: excellent $-7 \%$, good $-72 \%$, average $5 \%$, poor $-2 \%$, while $14 \%$ of the respondents have not been able to state their point. Being prepared for the competition in the labor market has been rated in a similar way: 
excellent $-9 \%$, good $-63 \%$, average $6 \%$, poor $-2 \%$, while $20 \%$ of the respondents have not been able to give a definite answer.

Almost all the respondents involved in the survey (96\%) believe that the curricula of the institutions of higher education have to be improved, while the remaining $4 \%$ have chosen the option hard to say.

\section{Discussion}

The results of the study give an overall impression of the views of the $1^{\text {st }}$ year students concerning the role of innovations and traditions at their institution of higher education and their understanding of innovative processes. It has to be acknowledged that both full-time and part-time students have evaluated the introduction of innovations equally positively, since there are no statistically significant differences between both student samples.

Overall, the students have a positive attitude to the introduction of innovations in the study process. However, as to the ways of introducing innovations, they do not see the importance of bottom-up innovations (initiated by students themselves) and traditionally place the responsibility for introducing innovations on the administration of the institution of higher education. Although a similar situation is mentioned in the works of other authors (e.g., Kezar, 2012), it has to be admitted that the number of the supporters of top-down innovations is surprisingly large $(72 \%)$ in view of the fact that in institutions of higher education innovations currently are an integral part of the study process. A view like this indicates the lack of enterprise and initiative among the respondents. Though, the individual behavior of a student cannot be explained without understanding the context of their life. Social conditions can create opportunities for the autonomous development of each individual, but they also determine the manner and the ways these individuals have to act. Individuals can perceive themselves as free and emancipated human beings; however, secondary agents (market, politics) affect their biography to a large extent (Beck \& Ritter, 1992). The situation where students have to combine work and studies in order to obtain education reduces the time of their participation in initiating innovative processes at their institution of higher education.

The respondents express their support for the preservation of traditional teaching methods, but they also appreciate the introduction of novel methods. The majority of the respondents $(71 \%)$ think that innovations have to be introduced gradually. The students emphasize the integration of innovations and traditions in the process of studies and point out that it is necessary to advisedly coordinate the introduction of innovations with the effective experience from the past. This finding coincides with other studies (Kunda, 2014; Miller et al., 2013). The dominance of incremental innovations identified in the study also corresponds with the conclusions found in other studies (Silver et al., 1997).

Some questions have presented difficulties to the respondents, where up to $15 \%$ of sample has not been able to give a definite answer (see Table 1). In contrast, the question concerning the attitude to the introduction of innovations has been very easy - almost $90 \%$ of the respondents have stated that the attitudes of both students and educators have to be positive. 
As to the role of teacher's personality, almost all the respondents $(96 \%)$ recognize the important role of the academic staff in the study process. The innovation requires people who could promote them, develop ideas, and find their practical application. The promoters of innovations - teachers and students - have been referred to as the human factor of innovation (Lapina, 2007) fostering the implementation of new ideas that can bring positive changes in education like the development of new curricula, the introduction of new interactive teaching methods, and the training of innovative specialists for working life. The studies carried out by various authors indicate that innovative specialists are characterized by specific personal qualities, theoretical knowledge and practical expertise in their specialty and related fields, as well as the culture of innovation (Baranova, 2012; Koḳe, 1999; Lapina, 2007; Porter, 1998; Žogla, 2001). Hence, the shift in the role of the academic staff from the dominant role of experts in the traditional study process to the role of a guide, supporter, consultant, coordinator, and facilitator in a student-centered process of studies is observed (Žogla, 2001). In the context of the present study, it has to be mentioned that teacher's presence is particularly important during the adaptation process of the first year students since it is the teacher who can recognize student's abilities and needs and provide the necessary support (Odina, 2010).

In view of the fact that the respondents of the study had fresh memories from recently finished secondary school and they also have already drawn some conclusions during their first year of studies, the results of this research clearly show that students appreciate the professionalism $(84 \%)$, intelligence $(72 \%)$, and erudition $(67 \%)$ of the academic staff. Besides, they rate as important those qualities that promote collaboration between the teacher and learners - respect for students, self-respect, and determination. Moreover, the students believe that teacher can be an intellectual leader. The results of the study also prove the previously expressed beliefs (Mūrnieks, 2010), that the contemporary higher education has not only the practical task of preparing people for working life, which is positively rated by the students, but it also performs the functions of humanization and acculturation. The study confirms the idea that collaboration is the means of implementing innovative pedagogy where an educator and learners are searching for the truth together (Kettunen et al., 2013; Mūrnieks, 2010; Tillıa, 2005). Therefore, the students rate negatively those personal qualities of the academic staff that do not promote mutual understanding in the study process, such as unwillingness to accept different opinion and indifference.

If we proceed from the thesis put forward by Gibbons and his colleagues (Gibbons, Limoges, Nowotny, Schwartzman, \& Scott, 1994) concerning the implementation of a new socially extended, collaborative model of activity at the institutions of higher education, it is necessary to maintain a broader and multiform dialog between the administration of the departments, program directors, and students. It also implies playing in different fields (studies, research, and the circle of social agents), as well as communication with all stakeholders (schools, institutions of higher education, employers). The results of the given study coincide with the studies related to the change management conducted in other countries. For instance, as far as the study process is concerned, the present system of institutions of higher education has been found to be hindering the progress rather than facilitating communication, innovation, and creativity (Jongbloed, Enders, \& Salerno, 2008). The studies carried out in Latvia show that internal obstacles to broader innovative changes are related to the cooperation between the students and the adminis- 
tration of an institution, while improving communication might be the way to overcome this present separation. Adequate attention has not been paid to the development of the traditions of collegiate democracy and mentoring (Baltušìte, 2012; Lapina, 2007).

The study that analyzes teachers' views on innovative change shows that teachers expect the initiative for innovations from professional organizations and school administration, while the manifestations of self-initiative are not duly appreciated (Mürnieks, 2010). This leads to the conclusion that the personal experience gained at school is still an important factor for the first year students, and changing the work environment at the institutions of higher education is a topical issue.

One of the limitations of given study is that this study reveals the views of the first year students in one particular institution of higher education that can not be extrapolated to an entire population. Though, the results of the study can be used to promote further research concerning the innovative and traditional elements in sustainable education. The obtained findings make it possible to set the directions of further explorative activity in order to conduct more extensive national or international comparative research to acknowledge and evaluate the best innovative practice in teacher education.

\section{Conclusions}

In teacher education, the notion 'innovation' has a complex and multifaceted meaning. It refers to the process of renewal, educational reforms, the selection of the most appropriate teaching materials (idea, activity, form, method, means, concept, or program) and the creation, acquisition, and application of innovations in the pedagogical practice.

The results of this study give some insight in the innovative processes at one institution of higher education in Latvia from the point of view of students - pre-service teachers. The students have noticed the innovations in all the roles of the institution of higher education - the study process, research, and social engagement.

Besides, the students have shown their willingness to participate in the introduction of innovations and they evaluate the preservation of the traditional experience of the study process positively. The students believe that incremental innovations, i.e. the gradual harmonization of traditions and innovations, are appropriate in the study process. On the other hand, majority of the sample demonstrated the lack of self-initiative and gave preference to innovations initiated by some central authority (the administration of the institution). This view implies the need to have more extensive and multiform communication with the $1^{\text {st }}$ year students that would promote students' participation in the implementation of innovations at the institution of higher education.

Innovations have been evaluated most positively in the context of teacher-student interaction - educators' cooperation with students enhancing their interest in innovations. Students appreciate the role of the academic staff in the innovative processes recognizing them as their intellectual leaders. Professionalism is the most highly rated personal quality of the academic staff.

Following the results of the study, some recommendations can be proposed with regard to the sustainability of teacher education. One suggestion would be to promote an open dialogue between teachers, students, and the administration of the institution about the quality of studies and the operation of the whole institution. This would help 
to identify barriers and facilitate the introduction of innovations at the given institution. Also, the students' views identified in the study would be useful for the staff responsible for the adaptation of the first year students at the institution of higher education and those engaged in the activities of student self-government, thus expanding the range of agents involved in the creation of knowledge and solving complex practical problems.

\section{References}

Alange, S., Jacobsson, S., \& Jarnehammar, A. (1998). Some aspects of an analytical framework for studying the diffusion of organizational innovations. Technology Analysis and Strategic Management, 10(1), 3-21.

Baltušite, R. (2012). The pedagogy students' readiness for professional activities in the school environment (Synopsis of the doctoral dissertation, Latvia University of Agriculture, Latvia). Retrieved June 3, 2015, from http://llufb.llu.lv/dissertationsummary/pedagogics/Regiina_Baltusiite_promoc_darba_kopsavilkums_2013_ LLU_TF_IMI.pdf

Baranova, S. (2012). Augstskolu docētāju profesionālā pilnveide tālākizglìtībā [Professional development of the university faculty in further education] (Doctoral dissertation, University of Latvia, Latvia). Retrieved May 23, 2015, from https://dspace. lu.lv/dspace/handle/7/4670

Beck, U., \& Ritter, M. (1992). Risk society: Towards a new modernity. New Delhi: Sage.

Brigmane, B. (2014). Pieaugušo pašpieredzes veidošanās mācǐšanās procesā [The formation of adults' self-experience in the process of learning] (Doctoral dissertation, Riga Teacher Training and Educational Management Academy, Latvia). Retrieved May 20, 2015, from http://www.rpiva.lv/pdf/prom/bb_darbs.pdf

Brunori, G., Berti, G., Kleikx, L., Tisenkopfs, T., \& Rolp, D. (2011). Learning and innovation networks for sustainable agriculture: A conceptual framework. Brussels: Solinsa.

Cavanagh, M. (2011). Students experiences of active engagement through cooperative learning activities in lecture. Active Learning in Higher Education, 12(1), 23-33.

CEDEFOP (The European Centre for the Development of Vocational Training). (2008). Future skill needs in Europe. Medium-term forecast. Luxembourg: Office for Official Publications of the European Communities.

Cummings, R. (2005). Middle-out approaches to reform of university teaching and learning: Champions studying between the top-down and bottom-up approaches. The International Review of Research in Open and Distance Learning, 6(1), 1-18.

Dewey, J. (1938). Experience and education. New York, NY: Kappa.

Ferrari, A., Cachia, R., \& Punie, Y. (2009). Innovation and creativity in education and training in the EU member states: Fostering creative learning and supporting innovative teaching. Luxembourg: Office for Official Publications of the European Communities.

Fried, I. (2006). Higher education governance in Europe: Autonomy, ownership and accountability: A review of the literature. In J. Kohler \& I. Huber (Eds.), Higher education governance between democratic culture, academic aspirations and market forces. Brussels: Council of Europe Publishing, Series, No. 5. 
Gedžūne, I. (2014). Orientation of pre-service teachers' frames of reference towards inclusion in nature (Synopsis of the doctoral dissertation, Daugavpils University, Latvia). Retrieved June 3, 2015, from http://du.lv/files/000/009/575/inga_gedzune_ promocijas_darbs_saved.pdf?1399888263

Gibbons, M., Limoges, C., Nowotny, H., Schwartzman, S., \& Scott, P. (1994). The new production of knowledge: The dynamic of science and research in contemporary societies. London: Sage.

Grabovska, R. (2006). Ilgtspējības principa īstenošana skolotāju izglìtībā [The implementation of the principle of sustainability in teacher education] (Doctoral dissertation Daugavpils University, Latvia). Retrieved June 12, 2015, from www3.acadlib.lv/ greydoc/Grabovskas_disertacija/Grabovska_lat.doc

Grabovska, R., \& Grabovskis, J. (2009). Implementing the United Nations Decade on Education for Sustainable Development in Latvian higher education. Journal of Teacher Education for Sustainability, 11(1), 18-30.

Hannan, A., \& Silver, H. (2000). Innovating in higher education: Teaching, learning and institutional cultures. Buckinhgham: The Society for Research into Higher Education and Open University Press.

Jongbloed, B., Enders, J., \& Salerno, C. (2008). Higher education and its communities: Interconnections, interdependencies and a research agenda. Higher Education, 56, 303-324.

Kapenieks, J. (2013). Izglìtības darbības pètījums e-studiju vidē [Educational action research design for e-learning environments] (Doctoral dissertation, Riga Technical University, Latvia). Retrieved June 13, 2015, from http:/www.liepu.lv/uploads/ files/KapenieksJ_Promocijas\%20darbs.pdf

Kapenieks, J., \& Salite, I. (2012). Action research for creating knowledge in an e-environment. Journal of Teacher Education for Sustainability, 14(2), 111-129. doi: 10.2478/ v10099-012-0012-x

Kettunen, J., Kairisto-Mertanen, L., \& Penttila, T. (2013). Innovation pedagogy and desired learning outcomes in higher education. On the Horizon, 21(4), 333-342.

Kezar, A. (2012). Bottom-up/top-down leadership: Contradictions or hidden phenomenon. The Journal of Higher Education, 83(5), 725-760.

Koḳe, T. (1999). Pieaugušo izglìtības attīstība: Raksturīgākās iezìmes [The development of adult education: The key features]. Rīga: Mācību apgāds NT.

Kunda, I. (2014). Inovācijas universitātē: Varas un leóitimitātes aspekti [Innovations at university: Aspects of power and legitimacy] (Doctoral dissertation, University of Latvia, Latvia). Retrieved May 15, 2015, from http://www.szf.lu.lv/fileadmin/ user_upload/szf_faili/Bauhausi/Kunda_Ilona_2014.pdf

Lapina, G. (2007). Inovācijas pedagogiskā izpratne augstskolā [Pedagogical comprehension of innovation in higher education] (Doctoral dissertation, University of Latvia, Latvia). Retrieved May 15, 2015, from https://dspace.lu.lv/dspace/bitstream/ handle/7/4768/28662-Gundega_Lapina_2008.pdf?sequence $=1$

Lukjanska, R. (2014). The analysis of the innovation capacity in Latvia in the context of the European region (Synopsis of doctoral dissertation, Latvian University of Agriculture, Latvia). Retrieved April 24, 2015, from http://llufb.llu.lv/dissertationsummary/economics/Renate_Lukjanska_promoc_darba_kopsav_2014_LLU_ ESAF.pdf 
McKenzie, J., Aleksander, S., Harper, C., \& Anderson, S. (2005). Dissemination, adoption and adaptation of project innovations in higher education. Sydney: UTS Printing Services. Retrieved April 3, 2015, from http://epress.lib.uts.edu/au/research/handle/ 10453/12236

Miller, C. J., McNear, I., \& Metz, M. J. (2013). A comparison of traditional and engaging lecture methods in a large, professional-level-course. Advances in Physiology Education, 37, 347-355.

Mūrnieks, A. (2010). Influence of the society culture on development of educational aims in education management in Latvia (Synopsis of doctoral dissertation, University of Latvia, Latvia). Retrieved May 5, 2015, from http://www.lu.lv/fileadmin/ user_upload/lu_portal/zinas/Andrejs_Murnieks_Promocijas_darba_ kopsavilkums.pdf

Odiņa, I. (2010). Pirmā studiju gada studentu adaptēšanās medicinas koledžas pedagogiskajā vide [The adaptation of the $1^{\text {st }}$ year students in the pedagogical environment of a medical college] (Doctoral dissertation, University of Latvia, Latvia). Retrieved May 3, 2015, from https://dspace.lu.lv/dspace/handle/7/4629

Porter, M. (1998). On competition. USA: Harward Business Review.

Prensky, M. (2001). Digital game-based learning. New York: McGraw-Hill.

Prensky, M. (2005). Engage me or enrage me: What today's learners demand. Education Review, 40, 60-65.

Reason, P., \& Bradbury, H. (2008). Introduction. In P. Reason \& H. Bradbury (Eds.), The SAGE handbook of action research (pp. 1-16). London: Sage Publications.

Robinson, K. (2011). Out of our minds. Learning to be creative. Chichester, UK: Wiley. Salìte, I., Gedžūne, G., \& Gedžūne, I. (2009). Educational action research for sustainability: Seeking wisdom of insight in teacher education. Journal of Teacher Education for Sustainability, 11(2), 14-30. doi: 10.2478/v10099-009-0037-y

Shattock, M. (2008). Entrepreneuralism in universities and the knowledge economy: Diversification and organizational change in European higher education. Open University Press.

Silver, H., Hannan, A., \& English, S. (1997). Innovation: Questions of boundary. ESRC Learning Society Programme, Working Paper No. 2. Retrieved May 5, 2015, from http://www.leeds.ac.uk/educol/documents/000000674.htm

Stankevičs, A. (2015). The role of higher education in increasing the performance of a region (Synopsis of doctoral dissertation, Daugavpils University, Latvia). Retrieved April 9, 2015, from http://du.lv/files/000/010/945/Aivara_Stankevica_ kopsavilkums_save.pdf?1422886125

Stensaker, B., \& Norgard, J. D. (2001). Innovation and isomorphism: A case study of university identity struggle 1969-1999. Higher Education, 42, 473-492.

The Cabinet of Ministers of the Republic of Latvia. (2013). Zinātnes, tehnologijas attīstības un inovācijas pamatnostādnes 2014.-2020. gadam [The guidelines for science, the development of technologies and innovations for the period of 2014-2020]. Retrieved April 1, 2015, from http://likumi.lv/doc.php?id=263464

Tiḷ̂a, I. (2005). Sociālkultūras mācīšanās organizācijas sistēma [The organisational system for the studies of social culture]. Riga: RaKa.

Tisenkops, T., Bela, B., \& Kunda, I. (2011). Augstskolas reǵionos: Zināšanu un prakses mijiedarbe [Institutions of higher education in the regions: The interaction of knowledge and practice]. Rīga: Zinātne. 
UNESCO (United Nations Educational, Scientific and Cultural Organisation). (2005). Guidelines and recommendations for reorienting teacher education to address sustainability. Education for Sustainable Development in action. Technical Paper No. 2, October 2005.

Van Dijk, S., Berends, H., Jelinek, M., Romme, A. G. L., \& Weggeman, M. (2011). Micro-institutional affordances and strategies of radical innovation. Organization Studies, 32(11), 1485-1513.

Woods, P. (2002). Teaching and learning in the new millennium. In C. Day \& C. Sugrue (Eds.), Developing teachers and teaching practice (pp. 73-91). London: Routledge \& Falmer.

Zietsma, C., \& Lawrence, T. B. (2010). Institutional work in the transformation of an organizational field: The interplay of boundary work and practice work. Administrative Science Quarterly, 55(2), 189-221.

Žogla, I. (2001). Didaktikas teorêtiskie pamati [The theoretical foundations of didactics]. Rìga: RaKa.

Correspondence concerning this paper should be addressed to Prof. Dr. Inese Jurgena, Riga Teacher Training and Educational Management Academy, 7/1 Imantas linija, LV-1083, Riga, Latvia. Email: inese.jurgena@rpiva.lv 